\title{
Agreement in Kimbeere Relative Clauses
}

\author{
Peter Kinyua Muriungi ${ }^{1}$, Nancy Mbandi Mutange ${ }^{2}$ \\ ${ }^{1}$ Principal Tharaka University College, Gatunga, Kenya \\ ${ }^{2}$ Chuka University, Chuka, Kenya \\ Email: muriungip@gmail.com
}

How to cite this paper: Muriungi, P. K., \& Mutange, N. M. (2019). Agreement in Kimbeere Relative Clauses. Open Journal of Modern Linguistics, 9, 580-590. https://doi.org/10.4236/ojml.2019.96042

Received: March 10, 2019

Accepted: December 20, 2019

Published: December 23, 2019

Copyright ( 2019 by author(s) and Scientific Research Publishing Inc. This work is licensed under the Creative Commons Attribution International License (CC BY 4.0).

http://creativecommons.org/licenses/by/4.0/

\section{c) (i) Open Access}

\begin{abstract}
This paper demonstrates that the two relative markers "-rĩa" and "-ĩngĩ" agree with the head noun in Kimbeere. The agreement is determined by the class of the Head noun.
\end{abstract}

\section{Keywords}

Head Noun, Relative Marker, Agreement

\section{Introduction}

This paper demonstrates how head nouns agree with their markers in Kimbeere relative clauses. The article is organized as follows: In Section 2, we show how agreement between the relative marker and each of the sixteen Kimbeere noun classes occurs. In Section 3, we compare the morphology of Kimbeere "-rĩa" relatives with "-ĩngî" relatives and other Bantu languages forms. Sections 4 and 5 contain the findings of this study and conclusion respectively.

\section{Morphological Analysis}

Kinyua (2010) demonstrated how several morphemes can be realized in one Kimwimbi verb. Refer to (1) in which " $B a$ " is an agreement morpheme, " $r \overrightarrow{1}$ " is a tense morpheme, " $m \tilde{u}$ " is object marker, "ring" is the root, " $\tilde{i r}$ " is a morpheme meaning applicative and " $a$ " is the final vowel.

(1) Barĩmũringĩra.

$\begin{array}{llllll}\text { Ba- } & \text { rĩ- } & \text { mũ- } & \text { ring- } & \text { ĩr- } & \text { a. } \\ \text { AM } & \text { TM } & \text { OM } & \text { Root } & \text { Appl- } & \text { FV }\end{array}$

"They are calling him"

Kinyua's study was relevant in that it helped the researcher to single out morphemes marking subjects, objects, relatives, tenses and the verb root. In Kimbeere relative clauses, the relative marker "rĩa" is preceded by an agreement 
marker (AM) which agrees in class and number with the head noun in a systematic way. Consider examples (2a-c) below.
a) Iratũ
irĩa
8.Shoes
8.which
b) Gĩkombe
kĩrĩa
7.Cup
7.which
c) İtumbĩ
rĩrĩa
5.Egg
5.which

It is evident that the noun "iratü" (shoes) which is in noun class 8 agrees with the prefix " $i$ " in "irĩa" (which), which is also in noun class 8 because they refer to the same entity, "iratũ" (shoes). Similarly, "gîkombe" agrees with "kî" in "kĩrĩa" (which) all in noun class 7; and "îtumbî" and "rî" in "îtumbĩ rĩrĩa" (egg which) all in noun class 5 agree in class and number. This consistency in pattern is noticed in all the relative clauses discussed in this study.

Gitonga (2014), in his study titled "Upatanishi Katika Sentensi ya Kichuka" (Agreement in Kichuka Sentence), demonstrated that there is agreement in noun phrases and verb phrases within a sentence. Structure (3) exemplifies this.

(3) Maembe matano matagũrwa

$\begin{array}{lllll}\text { Maembe } & \text { ma-tano } & \text { ma-ta- } & \text { gũr- } & \text { w- a. } \\ \text { 6.mangoes } & \text { 6-five } & \text { 6-NEG buy- } & \text { PASS-FV } \\ \text { Maembe } & \text { matano } & \text { hayakununuliwa } & \text { (Kiswahili). } \\ \text { Mangoes } & \text { five } & \text { they were not bought. } & \end{array}$

"Five mangoes were not bought"

Evidently "ma-" in "maembe" (object) agrees with "ma-" in "matano" (number/quantifier) and "ma-" in "matagũrwa" (object marker + Verb). This agreement is necessary in the formation of Kimbeere relative clauses.

The noun agreement marker for class 1 and 2 is ũand $a$ as in "mũndũ ũrãaandũ arĩa" (person who-people who); class 3 and 4 is $\tilde{u}$ and $\tilde{I}$ as in "mũtĩ ũrĩamĩtĩ Irrĩa" (tree which-trees which); class 5 and 6 is rĩ and $m a$ as in "ígemberĩrĩamagembe marĩa" (mango which-mangoes which); class 7 and 8 is kĩ and $i$ as in "gĩciko kĩria-iciko irĩa" (spoon which-spoons which); class 9 and 10 isĩ and $i$ as in "mbũriñrĩa-mbũri irĩa" (goat which-goats which); class 11 and 12 is rũ and $k a$ as in "rũkũ rũrĩa-karamu karĩa" (piece of wood which-pen which); class 13 and 14 is tũ and $\tilde{u}$ as in "tũramu tũrĩa-ũuukĩ ũrãa" (pens which-honey which); class 15 and 16 is kũ and ba as in "kũndũ kũrãa-bandũ barĩa" (place which-places which). Table 1 summarizes agreement between nouns and the morphemes representing them in Kimbeere "-rĩa" relative clauses.

From Table 1, we gather that the relative marker agrees with the head noun of the relative clause. This agreement issystematic and consistent in all the noun classes listed. For example in "mũtĩ ũ-rĩa" (tree which), the noun "mũtî" which is in noun class 3 and in singular agrees with the agreement morpheme " $\tilde{u}-"$ in "ũrĩa" which is also in noun class 3 singular. The plural of "mũtĩ $\tilde{u}$-rĩa" is "mĩti

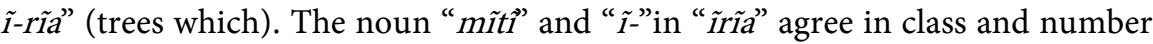


Table 1. Kimbeere noun class agreement.

\begin{tabular}{|c|c|c|c|}
\hline Noun class & Noun & Noun Agr. Marker & Rel. Morpheme \\
\hline 1 & mũ-ndũ & $\tilde{\mathbf{u}}-$ & -rĩa \\
\hline 2 & a-ndũ & a- & -rĩa \\
\hline 3 & mũ-tĩ & $\tilde{\mathbf{u}}-$ & -rĩa \\
\hline 4 & mĩ-tĩ & $\tilde{\mathbf{1}}^{-}$ & -rĩa \\
\hline 5 & rĩ-ĩtwa & rĩ- & -rĩa \\
\hline 6 & ma-rĩitwa & ma- & -rĩa \\
\hline 7 & kĩ-ondo & kĩ- & -rĩa \\
\hline 8 & ci-ondo & i- & -rĩa \\
\hline 9 & ngi-tĩ & $\tilde{\mathbf{1}}-$ & -rĩa \\
\hline 10 & ngi-tĩ & i- & -rĩa \\
\hline 11 & rũ-rigi & rũ- & -rĩa \\
\hline 10 & ndi-gi & i- & -rĩa \\
\hline 12 & ka-nya & ka- & -rĩa \\
\hline 13 & tũ-nya & tũ- & -rĩa \\
\hline 14 & $\tilde{\text { ũ-cũrũ }}$ & $\tilde{\mathbf{u}}-$ & -rĩa \\
\hline 6 & ma-cũrũ & ma- & -rĩa \\
\hline 15 & kũ-gũrũ & kũ- & -rĩa \\
\hline 6 & ma-gũrũ & ma- & -rĩa \\
\hline $15 \mathrm{~A}$ & kũ-thiĩ & kũ & -rĩa \\
\hline 16 & ba-ndũ & ba- & -rĩa \\
\hline $15 B$ & kũ-ndũ & kũ & -rĩa \\
\hline
\end{tabular}

since they are in noun class 4 and in plural as labeled in the table. It is worth noting that in the majority of cases, the agreement marker attached to the relative marker resembles the class prefix. For example in "a-ndũ a-rĩa" (people who) "a" in "andû" resembles "a" in "arara". The same can be said of "rũ -rigi rũ-rĩa" (string which), "tũnya tũrĩa" (little gourds which), "kĩondo kĩrĩa” (basket which), "kũgũrũkũrĩa" (leg which), "ũcũrũ ũrĩa" (porridge which) and "bandũbarĩa" (place which). Consider the examples in sentences (4) to (21).

(4) Mũndũ ũrĩa twatiga ndukarĩ nĩ mwirũ.

Mũndũ ũ-rĩatũ- a-tig- a nduka-rĩ nĩ mw-

1.person-1-REL-1sg- PST-leave-FV 9.shop- in FOC 1-

irũ

black

"The person we have left in the shop is dark"

(5) Andũ arĩa aaria nĩ akeni.

Andũ a-rĩa a- aria nĩ $\quad$ a- keni

2.people 2-REL 2- talkative FOC 2- happy

"People who are talkative are happy"

(6) Thĩ̃ ũteme mũtĩ ũrĩa mũmũ.

Thiĩ ũ- teme mũtĩ ũ-rĩa $m$ - ũmũ

Go 2sg-cut 3.tree 3-REL 3- dry

"You go cut the tree which is dry"

(7) Mĩtĩ ĩrĩa mĩraca nĩ mĩrũngarũ.

Mĩtĩ ĩ-rĩa mĩ- raca nĩ mĩ- rũngarũ

4.trees 4-REL 4- long FOC4- straight 
"The trees which are tall are straight"

(8) Nĩ warĩmĩra ĩrigũ rĩrĩa rĩkubĩ?

Nĩ w- a- rĩm- ĩr- a ĩrigũ rĩ-rĩa rĩ-kubĩ

FOC 1sg- PST-weed- Compl FV 5.banana 5-REL 5-short

"He/she has weeded for the short banana stem"

(9) Marigũ marĩa marathi tĩ mega ma kũrĩa.

Marigũ ma-rĩa ma-rathi tĩ ma-ega ma kũrĩa

6.bananas 6-REL 6-semi ripe NEG 6-good 6 to eat

"Bananas which are semi-ripe are not good for eating"

(10) Kĩondo kĩrĩa gĩtune kĩrĩ na gĩko.

Kĩondo kĩ-rĩa gĩ- tune k-ĩrĩ na gîko

7.basket 7-REL 7- red 7-has with dirt

The basket which is red has dirt

"The red basket is dirty"

(11) Ciondo irĩa ciabĩbirue ciarĩ ciake.

Ciondo i-rĩa ci- a- bĩb-ir w- e ci-arĩ

8.baskets 8-REL 8- PSt- burn-Compl PASS-FV 8-AUX

ci-ake

8-POSS

"The baskets which were burnt were his/hers"

(12) Mũthũngũ nũragũrire ngitĩ ĩrĩa mbaganu.

Mũthũngũ nĩ- ũ-ra- gũr-ir- e ngitĩ ĩ-rĩa mb-aganu 1.white personFOC-1-PST-buy-Compl-FV 9.dog 9-REL 9-fierce

"The white man/woman bought the dog which is fierce"

(13) Ngitĩ irĩa ngũrũ itirĩ magego.

Ngitĩ i-rĩa ng- ũrũ i- $t-$ irĩ magego

10.dogs 10-REL 10- old 10- NEG-have 6.teeth

"Dogs which are old don't have teeth"

(14) Tũkagũra rũrigi rũrĩa rũcerũ.

Tũ ka- gũr- a rũrigi rũ-rĩa

1pl FUT- buy-FV 11.string 11-REL 11-white

We will buy the string which is white

"We will buy the white string"

(15) Kabiũ karĩa kaũgĩ mũno karĩ kũ?

Kabiũ ka-rĩa ka-ũgĩ mũno ka-rĩ kũ

12.knife 12-REL 12-sharp very 12-AUX where

The knife which is sharp very is where?

"Where is the knife which is very sharp?"

(16) Tũcungi tũrĩa twerũ nĩ twabĩa.

Tũcungi tũ-rĩa tũ-erũ nĩ tũ- a- bĩa

13.sieves 13-REL 13-new FOC 13- PST - burn

"The sieves which are new have burnt"

(17) Ũcũrũ ũrĩa mwega nĩ wa mũbĩa.

Ũcũrũ mũ-rĩa mũ nũ mãbĩa 
14.porridge 14-REL 14-good FOC for 3.sorghum

The porridge which is good is for sorghum

"Sorghum flour porridge is better"

(18) Nĩnona kũgũrũ kũrĩa Wanja araunĩkire.

Nĩ- na- ona kũgũrũ kũ-rĩa Wanja a-ra- unĩk-ir- e

FOC-AUX-see 15.leg 15-REL 3sg 3-PST- break-PERF-FV

"I have seen the leg which Wanja broke"

(19) Kũtheka kũrĩa John athekaga tĩ kwega.

Kũtheka kũ-rĩa John a- thek-ag- a tĩ

15A.Tolaugh 15A-REL 3sg 3- laugh-HAB- FV NEG

kũ-ega

15A-good

To laugh which John laughs is not good

"The laughing which John laughs is not good"

(20) Kũndũ kũrĩa kũrĩ mĩtĩ nĩ kũthaka.

Kũndũ kũ-rĩa kũ-rĩ mĩtĩ nĩ kũ- thaka

15B.place 15B-REL 15B-has 4.miti FOC 15B- beautiful

"A place which has trees is beautiful"

(21) Bandũ barĩa batheru nĩ bathambie.

Bandũ ba-rĩa ba-theru nĩ
16.place 16-REL 16-clean FOC 16 - cleaned
"The place which is clean is washed"

Worth noting is the uniformity in the form of the relative morpheme "-rĩa". It is the same from noun class 1 to noun class 16 . Variations occur only in the noun agreement markers which are dictated by the noun class in question. For example in noun classes $2,6,7$, and 14, the noun agreement markers are " $a$-", "ma-" " $k \tilde{I}_{-}$" and " $\tilde{u}-$ " respectively. These noun agreement markers agree with the

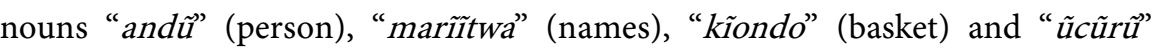
(porridge) in that order.

The agreement in Table 1 closely resembles what Ntarangwi (2015) came up with for Gitigania, a Kimeru dialect. In her study, Ntarangwi analyzes subject and object agreement markers as in (22) for noun classes 1 and 2.

$\begin{array}{llllll}\text { (22) } & \text { NC } & \text { Prefix } & \text { Example } & \text { SM } & \text { OM } \\ 1 & \text { m- } & \text { Mwana } & \text { a- } & \text {-mũ- } \\ & & \text { Child } 1 & & \\ & & \text { Ageni } & \text { ba- } & \text { ba- } \\ & \text { Visitors } 2 & & \end{array}$

In (22) for class 1 , the subject marker is " $a$ " while the object marker is "-mũu-". Sentence (23) shows an example of Gitigania sentences used with subject and object markers.

(23) Carol akamĩkĩra mĩtĩ mbolea

$\begin{array}{lllllll}\text { Carol } & \text { a } & \text { ka } & \text { mĩ } & \text { ĩkĩra } & \text { mĩtĩ } & \text { mbolea } \\ \text { Carol 1 } & \text { SM 1 } & \text { FUT } & \text { OM 4 } & \text { add } & \text { trees 4 } & \text { manure 9 }\end{array}$

"Carol will add manure to the trees" 
In (23), the subject Carol agrees in class and number with the subject marker " $a$-". They are all in Class 1 singular. Similarly, the object "mîtî" in class 4 agrees with the object marker " $m \vec{\imath}$ " that is also in noun class 4 .

\section{Comparison of "-Ĩngĩ" and Other Relative Clause Types}

The morphology of the Kimbeeere restrictive, appositive, direct, indirect, headless/free and tenseless relative clauses is similar in that the relative marker is “-rĩa" for all of them. In “-ĩngî? relative clauses the relative marker is “-ĩng both cases, this relative marker agrees in number and class with the head noun of the relative clause in question. Structures (24) \& (25) give a morphological analysis of other types and "-ĩngî" type of Kimbeere relative clauses respectively. For both examples, tense is conveyed by a combination of an empty tense morpheme $(\mathrm{O})$ and the perfective (-ir-) morpheme.

(24)

Ngaari ĩrĩa tũonire ĩrakuiĩte nyaki.

\begin{tabular}{|c|c|c|c|c|c|c|}
\hline $\begin{array}{l}\text { Ngaari } \\
9 \text { Vehicle }\end{array}$ & $\tilde{I}^{-}$ & & Otũ- & on-ir- & $e$ & $\begin{array}{l}\tilde{1} \text {-ra- ku- } \\
\text { om PST-carrv }\end{array}$ \\
\hline ĩit- e & nyaki & & & & & \\
\hline
\end{tabular}

"The vehicle which we saw was carrying grass"

Ngaari ĩ̃ngĩ tũonire ĩakuĩite nyaki.

$\begin{array}{llllll}\text { Ngaari } & \tilde{I} & \tilde{I} \text { Iñ Otũ } & \text { on-ir } & \text { e } & \tilde{1}-\mathrm{ra}-\mathrm{ku}- \\ \text { 9.Vehicle } & \text { 9.OM } & \text { RM O1pl } & \text { see-Compl } & \text { FV } & \text { om }_{9} \text {-PST- } \\ \text { carry } & & & & & \\ \text { iñt- e nyaki } & & & & & \\ \text { PERF-FV 10.grass } & & & & \end{array}$

"Another vehicle we saw was carryinggrass"

Apparently examples (24) and (25) share form with the exception of the rela-

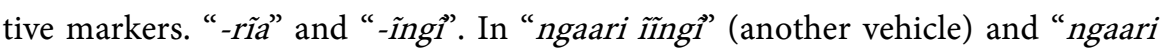
Irrãa" (vehicle which), "ngaari" (vehicle) which is in class 9 of the noun category agrees with the object marker " $\tilde{I}^{-}$" in " $\tilde{\mathbf{I}}$-ĩngîl" (another) and " $\tilde{\boldsymbol{I}}$-rĩa" (which). However, in the literal sense the two sentences differ in meaning considering that "ngaari irrĩa" (vehicle which) refers to a certain vehicle that "we saw" and which was carrying grass. On the other hand, "ngaari îngi" (another vehicle) seems to expresses a situation in which the speaker had seen a vehicle before the one mentioned in current speech, in other words the vehicle spoken about is an additional one. Ideally, a speaker would talk of "ngaari îngl" even when they have not seen a vehicle previously so that "ngaari îrĩa" and "ngaari î̃ng $\overrightarrow{1}$ " may not necessarily mean different things.

Generally for "-ĩngî" relative clauses there is a systematic agreement between noun classes and agreement markers attached to "-ingï". For class 1 and 2 the agreement marker is wĩ and eas in "mũndũ wiĩngĩ-andũ eengï" (person anoth-

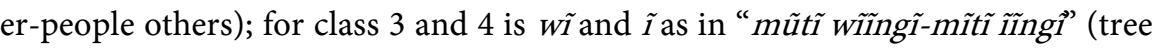
another-trees others); for class 5 and 6 is $r \tilde{1}$ and $m e$ as in "îtumbĩ rĩ̃ngĩmatumbĩ meengî"; for class 7 and 8 iskĩand $c i$ as in "kĩratũ kĩingĩiratũ ciĩngîl" 
(shoe another-shoes others); for class 9 and 10 is $\tilde{I}$ and $c i$ as in "ngũkũ $\tilde{I} n g \tilde{I}-$ ngũkũ ciĩngî" (chicken another-chickens others); for class 11 and 12 is rwĩ and keas in "rũuungũ rwĩ̃ngĩ-kameme keengî" (vine another-radio another); for class

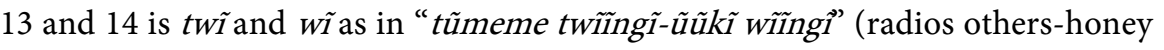

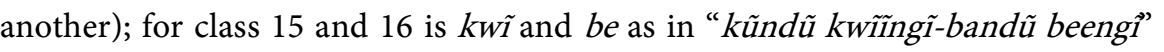
(places others-place another). These agreement patterns for “-ĩngî " relatives are summarized in Table 2.

From Table 2 we find that for "-ingg " relatives, the relative morpheme is also uniform just like in "-rĩa" relatives save for a few which inflect to agree with the final vowel of the noun agreement marker. For example in noun class 6 we have "marîitwa me-engî" (names others). The "-e" in "me-" influences the formation of the relative marker for agreement's sake. Therefore instead of saying "marĩitwa ma-ĩngi" the vowel sounds /a/ and /i/ combine to form /e/ hence "me-engï". This phenomenon is what Mgullu (1999) calls "mvutano wa irabu" (vowel attraction). In Kiswahili, says Mgullu, vowel attraction occurs mostly between vowel /a/, a low vowel and /i/, which is a high vowel. This attraction gives rise to the vowel sound $/ \mathcal{E} /$ which is in between vowel /a/ and vowel /i/. Consider the Kiswahili examples in (26) \& (27) for illustration. A similar scenario is exhibited in noun classes 12 as in "kanya ke-engi" (gourd another) and 16 as in "bandũ be-engì' (place another).
(26) ma+ingi
mengi
(27) wa+ ingi
wengi

(Mgullu, 1999)

Table 2. Kimbeere "-Ĩngî" noun classes agreement.

\begin{tabular}{|c|c|c|c|}
\hline Noun Class & Noun & NounPrefix & Rel. Morpheme \\
\hline 1 & mũndũ & wĩ- & -ĩngĩ \\
\hline 2 & andũ & e- & -engĩ \\
\hline 3 & mũtĩ & wĩ- & -ĩngĩ \\
\hline 4 & mĩtĩ & $\tilde{\mathbf{1}}^{-}$ & -ĩngĩ \\
\hline 5 & rĩitwa & rĩ- & -ĩngĩ \\
\hline 6 & marĩitwa & me- & -engĩ \\
\hline 7 & kĩondo & kĩ- & -ĩngĩ \\
\hline 8 & ciondo & ci- & -ĩngĩ \\
\hline 9 & ngitĩ & i- & -ĩngĩ \\
\hline 10 & ngitĩ & ci- & -ĩngĩ \\
\hline 11 & rũrigi & rwĩ- & -ĩngĩ \\
\hline 10 & ndigi & $\mathrm{ci}^{-}$ & -ĩngĩ \\
\hline 12 & kanya & ke- & -engĩ \\
\hline 13 & tũnya & twĩ- & -ĩngĩ \\
\hline 14 & ũcũrũ & wĩ- & -ĩngĩ \\
\hline 6 & macũrũ & me- & -engĩ \\
\hline 15 & kũgũrũ & kwĩ- & -ĩngĩ \\
\hline 6 & magũrũ & me- & -engĩ \\
\hline $15 \mathrm{~A}$ & kũthiĩ & kwĩ & -ĩngĩ \\
\hline 16 & bandũ & be- & -engĩ \\
\hline $15 B$ & kũndũ & kwĩ- & -ĩngĩ \\
\hline
\end{tabular}


Just like in other types of Kimbeere relative clauses, agreement between the relativized noun and the agreement marker attached to the relative morpheme is observable in "-ingl" relative clauses. For instance in (28) "kaana" (child) which is in noun class 12 agrees with "ke-" in "ke-engî" (another) which is also in class 12. See sentential examples for the 16 noun classes in (29) to (45).

(28) Kaana keengĩ nethĩre kanitharĩ nĩ karaũrire.

$\begin{array}{lllllll}\text { Kaana } & \text { keengĩ Ona- } & \text { ith } & \text { Ir } & e & \text { kanitha } & \text { rĩ } \\ \text { 12.Child } & \text { 12.REL-O1sg } & \text { find Appl } & \text { FV } & \text { 12.church Prep } \\ \text { nĩ ka- } & \text { ra- } & \text { urr- } & \text { ir- } & \text { e } & & \\ \text { FOC om } & \text { PST } & \text { lost } & \text { Compl } & \text { FV } & & \end{array}$

Child another I foundchurch in got lost

"Another child I found in church got lost"

(29) Mũndũ wĩ̃ngĩ ũrarĩ cukuru nĩ namwona.

Mũndũ wĩ-ĩngĩ ũ-rarĩ cukuru nĩ na- mũ- ona

1.person 1-REL 1-was school FOCPERF $\mathrm{om}_{1}$-see

Person another who was in school I have see

"I have seen another person who was in school"

(30) Nĩmwacemania na andũ eengĩ maracarua nĩ athigari?

Nĩ mũ- a-cemania na andũ e-engĩ ma- ra-

FOC 2pl- have-meet with 2.people 2-REL om $_{2}$-be

carua- nĩ athigari

search by 2.police

You have met with people othe being searched for by police

"Have you met other people who are being searched for by the police?"

(31) Mũtĩ wĩ̃ngĩ tũrenda gũtema nĩ mwariĩ.

Mũtĩ wĩ-ĩngĩtũ- ra-enda gũtema nĩ mũ- ariĩ

3.tree 3-REL 1pl- pres-want to cut $\mathrm{FOC} \mathrm{om}_{3}$-wide

Tree another we want to cut is wide

"Another tree we want to cut is wide"

(32) Ngakũonia mĩtĩ ĩ̃ngĩ ũkabanda.

Ng- a kũ- onia mĩtĩ ĩ-ĩngĩ ũ- ka-

1sg- FUT 2sg- show 4.trees 4-REL $\mathrm{sm}_{2}$-FUT- plant

I will show you tree others you will plant

"I will show you other trees you will plant"

(33) Ĩbuku rĩ̃ngĩ nĩrathoma nĩ rĩnene.

Ĩbuku rĩ-ĩngĩ nĩ- ra- thoma nĩ rĩ-nene

5.book 5-REL $\mathrm{sm}_{1}$ - pres-read is $\mathrm{om}_{5}$-big

Book another I am reading is big

"Another book I am reading is big"

(34) Mabati meengĩ Kariuki aratuma namo nĩ marotu.

Mabati me-engĩ Kariuki a-ra-tuma na-mo

6.iron sheets 6-REL 3Kariuki $\mathrm{sm}_{3}$-pres-build with-6

nĩ ma- rotu

FOC 6- rusty 
Iron sheets others Kariuki is building with are rusty

"Other iron sheets Kariuki is building with are rusty"

(35) Kĩratũ kĩingĩ kĩratetwe njĩrarĩ nĩ kĩaũ?

Kĩratũ kĩ-ĩngĩ kĩ- ra- tetwe njĩra-rĩ nĩ kĩ- aũ

7.shoe 7-REL 7- PST-thrown way-in is 7- whose

Shoe another had been thrown on the way is whose

"Whose is another shoe which had been thrown on the way"

(36) Ngaari ĩngĩ Mike aratwara tĩ yake.

Ngaari ĩ-ĩngĩ Mike a- ra- twara tĩ y-ake

9.vehicle 9-REL 3Mike $\mathrm{sm}_{3}$-pres-drive NEG 9-POSS

Vehicle another Mike is driving not his

"Another vehicle Mike is driving is not his"

(37) Ngaari ciĩngĩ ciakĩrĩra aba nĩ cia kambeni.

Ngaari ci-ĩngĩ ci-a- kĩrĩra aba nĩ ci-a

10.vehicles 10-REL 10-have- pass by here FOC 10-for

kambeni

campaign

Vehicle others they have passed here are for campaign

"Other campaign vehicles have passed by"

(38) Rũkũ rwĩ̃̃ngĩ waoca tĩ rũũmũ.

Rũkũ rwĩ-ĩngĩ $\quad$ w- a- oca tĩ $\quad$ rũ-ũmũ

11.firewood 11-REL 2sg-pres pick NEG om ${ }_{11}$-dry

Firewood another you have pick is not dry

"Another firewood you have picked is not dry"

(39) Ũkangũrĩra karamu keengĩ gatune.

Ũ- ka- n- gũr- ĩr- a karamu ke-engĩ

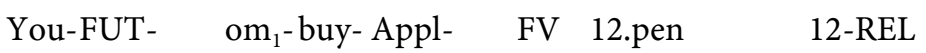

ga-tune

12-red

You buy for me pen another red

"You will buy another red pen for me"

(40) Tũramu twĩ̃ngĩ twaarĩ tũũru nĩ twoneka.

Tũramu twĩ-ĩngĩ tũ-arĩ tũ-ũru nĩ tũ-a oneka

13.pens 13-REL 13-were 13-lost FOC 13-have-find

Pens others they were lost they are found

"Other pens which had got lost have been found"

(41) Ũcũrũ wĩ̃ngĩ Ndegi arugĩite nĩ mũrũrũ.

Ũcũrũ wĩ-ĩngĩ Ndegi a- rug- ĩit- e nĩ

14.porridge 14-REL 3Ndegi $\mathrm{sm}_{3}$-cook-PERF- FV FOC

mũ-rũrũ

14-bitter

Porridge another Ndegi has cooked is bitter.

"Another porridge Ndegi has cooked is bitter" 
(42) Kũgũrũ kwĩ̃ngĩ kwa mbũri kuunĩku gũkobwa.

$\begin{array}{llllll}\text { Kũgũrũ } & \text { kwĩ-ĩngĩ } & \text { kwa mbũri } & \text { ku-unĩku } & \text { gũ-kaobwa } \\ \text { 15.leg } & \text { 15-REL } & \text { of } & \text { 9.goat } & \text { 15-broken } & \text { 15-FUT-tied }\end{array}$

Leg another of goat it broken it will be tied

“Another goat's broken limb will be bound"

(43) Gũtuĩka kwĩ̃ngĩ Njeru atuĩkaga nĩ gwa kũthekania.

Gũtuĩka kwĩ-ĩngĩ Njeru a- tuĩk -ag- a nĩ-gũ-

15A.to dance 15A-REL 3Njeru sm $_{3}$-dance-HAB- FV FOC-15A-

a kũ-thekania

for 15-laughable

To dance another Njeru dances is laughable

"Another dancing Njeru does is laughable"

(44) Kũndũ kwĩ̃ngĩ tũrarĩ tũkathiĩ rũciũ nĩ twatĩrua.

Kũndũ kwĩ-ĩngĩ tũ-rarĩ tũ- ka-thiĩ rũciũ nĩ

15B.place 15B-REL 1pl-were-1pl- FUT-go-tomorrow FOC

tũ- a tĩrua

1pl- have been stopped

Place another we were to go tomorrow we have been stopped

"We have been stopped from going to another place we were to go tomorrow"

(45) Kamĩtĩ nĩyonire bandũ beengĩ ba gũcemania.

Kamĩtĩ nĩ- $\tilde{\mathbf{1}}^{-}$on- ir-e bandũ be-engĩ

9.committee FOC-7- see-Compl-FV 16.place 16-REL

ba gũ-cemania

for to-meet

The committee found place another for to meet

"The committee found another place to meet"

\section{Summary of Research Findings}

The study found out that:

- All the other types of Kimbeere relative clauses have "-rĩa" as the relative marker except “-ing $\vec{\imath}$ ” relatives that have “-ing $\vec{\imath}$ ” as the relative marker.

- The relative markers "-rĩa" and "-inngi" are attached to the head noun markers and they agree in number and class in a systematic manner.

\section{Conclusion}

In this paper, we have provided the morphology of Kimbeere "-rĩa” relatives (those that have "-rĩa" as the relative marker) and "-ingî" relatives (those that use "-ing, as the relative marker) and demonstrated that these relative markers agree with the head noun.

\section{Conflicts of Interest}

The authors declare no conflicts of interest regarding the publication of this paper. 


\section{References}

Gitonga, J. (2014). Upatanishi Katika Sentensi ya Kichuka, Kenya. (Unpublished M. A. Thesis), Chuka Univesity.

Kinyua, G. (2010). A Descriptive Analysis of the Verb Group in the Kimwimbi Dialect of Kimeru Language of Kenya. (Unpublished M.A. Thesis), Chuka University.

Mgullu, R. S. (1999). Fonetiki, Fonologia na Mofolojia ya Kiswahili. Nairobi: Longhorn Publishers (Kenya) Ltd.

Ntarangwi, L. G. (2015). A Minimalist Analysis of Agreement Patterns in Gitigania, A Dialect of Kimeru Spoken in Meru County, Kenya. (Unpublished M. A. Thesis), Chuka University. 